\title{
A Volatile Interaction between Peacebuilding Priorities: Road Infrastructure (Re)construction and Land Rights in Afghanistan ${ }^{1}$
}

\author{
Jon Unruh and Mourad Shalaby \\ Department of Geography \\ McGill University
}

\begin{abstract}
The current approach to peacebuilding is to focus on the specific building blocks of the process. However such attention and building blocks are to date largely isolated from each other in their planning, analysis, implementation, and measures for success with regard to contributing to overall peace. While two of these, land rights and road infrastructure, are regarded separately as crucial to postwar recovery, their interaction has not yet been examined. This article looks at these two priorities for Afghanistan, and finds in their interaction a large and acute problem of land seizures which the government and the international community in-country are unable to manage. This land grabbing is a direct result of a context of pervasive corruption, ongoing conflict, a mistaken understanding of the nature of the benefits of road reconstruction, large-scale dislocation, and widespread use of explosive devices. Such a pervasive problem sets back recovery, detracts from durable peace, and fuels the insurgency.
\end{abstract}

Keywords: Afghanistan, land tenure, road infrastructure, peacebuilding. war-torn, recovery

\section{Introduction}

The international community's understanding of war-affected societies and the 'peace process' has progressed significantly in recent years, particularly with the ongoing and pressing need for effective approaches to deal with unstable, failed, recovering, volatile, and poorly governed states and their restive populations. As understanding grows with regard to how and why civil wars occur, end, and often recur, efforts now need to progress beyond the pursuit of individual peacebuilding priorities as separate endeavors, toward greater integration of these. Such a need comes with the realization that, 1) conflict related settings are profoundly different than stable settings; 2) peacebuilding priorities and their projects and policies, while derived and implemented separately and on their own merits, do in fact interact with each other on the ground in a largely unplanned and unexamined manner, 3) success in one priority of peacebuilding can cause problems in another, and 4) there can be unexpected and often volatile repercussions due to specific interactions between constituent parts of separate peacebuilding priorities.

1 POST PRINT: Unruh JD and *Shalaby M (2012) A volatile interaction between peacebuilding priorities: road infrastructure (re)construction and land rights in Afghanistan. Progress in Development Studies 12: 47-61. 
With the 'lessons learned' in peacebuilding now becoming more widely known, there emerges the opportunity to examine certain problematic interactions between specific priority areas in order to find ways to mitigate acutely negative outcomes at a minimum, and enhance the prospects for such interaction to contribute to durable peace more ideally.

While priority areas for peacebuilding can vary with the country and the conflict, two that are widely recognized as critically important are road infrastructure (re)construction, and the reconstitution of land and property rights systems. This article examines the highly problematic interaction between these two priorities for Afghanistan, focusing specifically on how the road (re)construction effort underway in the country intersects with the current land rights situation which the government, with assistance from the international community, are failing to stabilize.

The reconstruction of road infrastructure, and in many cases its construction for the first time in war-torn countries, is thought to contribute, on its own, to peacebuilding and postwar recovery in very substantial ways. Road (re)construction is intended to facilitate trade and economic linkages, facilitate access to schools, health clinics, courts and other services, boost agricultural yields, bring rural areas into commercial interaction with the marketplace, provide security to rural communities, and contribute to the development of other sectors (USAID 2009; USAID 2006; JICA 2004; JICA 2003; JICA 2006; JSCE 2002). The realization of these benefits are understood to be crucial to economic and livelihood recovery and development, and hence the presumed winning of hearts and minds in unstable and volatile socio-political settings (Mockaitis 2003; Meilahn 2007; USAID 2009; JICA 2004).

At the same time the reconstitution of land and property rights systems in conflict scenarios is fundamental for the return of dislocated populations, restitution, agricultural recovery and food security, broad economic recovery, dispute resolution, and the ability to address volatile ethnic, tribal and religious claims and attachments to lands (e.g., Bruch et al 2009; Unruh 2009). The reconstitution of functioning land and property rights systems is also thought to resolve an array of political problems associated with areas claimed vs. gained or lost in battle by different groups during a war (Banks 2007; Andre 2003; Unruh 2003, 2004). As well land rights problems are recognized as an important cause and catalyst for armed conflict (Bailliet 2003; Cohen 1993; Barquero 2004; Bruch et al 2009; Unruh 2009). For example, issues of ethnic cleansing, evictions, retribution, inequality in land and property, legal pluralism that favors some sectors of society over others, legal systems that are non-inclusive or exploitive, and land-related grievances and animosities, are all significant contributors to conflict scenarios (DW 2005; Unruh 2004; Bruch et al 2009; Cohen 1993; Wiley 2003).

However these two priority areas of peacebuilding do not interact in analysis, policy, planning, programming, implementation, or evaluation - and the Afghanistan case is 
particularly illustrative of this (USAID 2009; USAID 2006; JICA 2004; JICA 2003; JICA 2006; JSCE 2002). They do however interact quite robustly on the ground and among a recipient population in an unplanned and to date unexamined way, to produce very difficult outcomes, with some of these working significantly against peacebuilding. Such outcomes can be particularly problematic when their violent repercussions are seen as having a proximate cause, and a military response is considered to be the only approach to their resolution.

Apart from the ease of planning and implementation based on conventional, industry, international assistance, and disciplinary boundaries, the primary reason for not examining the interaction between priority peacebuilding areas in conflict contexts has been the prevailing assumption that implementation of activities and projects within priority areas will affect society and produce outcomes similar to what would be expected in stable settings (MRRD/MPW 2007; USAID 2009; JICA 2006). However one of the primary lessons learned from a variety of peacebuilding experiences is that conflict related settings are profoundly different in a wide variety of ways (Bruch et al 2009; UNEP 2009; Goovaerts et al 2007; Junne and Verkoren 2005). What such a difference means however to the interaction of specific peacebuilding priorities, is where much additional work is needed.

Subsequent to a description of the highly volatile interaction between road (re)construction and land rights in Afghanistan, the conflict-related contexts of these two peacebuilding priorities is examined, focusing on how they are very different than stable contexts and how they set the stage for pervasive land grabbing.

\section{Land Grabbing: A Volatile Outcome of the Road - Land Interaction}

This article makes the argument that a primary effect of the interaction between road (re)construction and land tenure in the prevailing context in Afghanistan is a large surge in widespread land grabbing. At its most fundamental, the large increases in land values brought on by road (re)construction ${ }^{2}$ occurring within a context of a debilitated capacity and status of both customary and statutory tenure systems, increased ease of access to lands (via roads), flourishing corruption, and the absence of many landowners, tenants, and their relatives/heirs due to dislocation, is what drives this phenomenon. Land grabbing in Afghanistan is so acute that it is thought to constitute a significant conflict related flashpoint, able to push the country into renewed civil unrest (IWPR 2008; Batson 2008), and even "decades of conflict" (PakTribune, 2003). In Afghanistan land grabbing by powerful interests, including government officials, militia commanders (Synovitz 2003; Sherin 2009) former military commanders, and members of parliament is pervasive, and firmly related to the large scale problems of corruption and dislocation (Irvine 2007). The range and complexity of land grabbing cases in the country is large,

2 It is because the benefits noted earlier are thought by some actors to be associated with road (re)construction, that land values are driven up making lands proximate to roads then vulnerable to land grabbing. 
lucrative, widely known, and has a volatile history (Rashid et al 2010; Irvine 2007; Batson 2008; Sherin 2009).

Of particular importance in the road (re)construction effort is the 3,000 kilometer Ring Road connecting Kabul, Herat, Kandahar and back to Kabul (Figure 1). When completed it is estimated that 60 percent of Afghans (approximately 17 million people) will live within $50 \mathrm{~km}$ of this road (USAID 2009). Its construction and connections to many areas of the hinterland by provincial and feeder roads and bridges (MRRD/MPW 2007), are being undertaken by a number of donors operating in different parts of the country. A large US endeavor is the construction of $715 \mathrm{~km}$ of the Northern Ring Road, which together with the rehabilitation of six provincial roads, and $0.4 \mathrm{~km}$ of bridges, is thought to benefit some 5.3 million people (USAID 2009). However of the nine provinces where the percentages of government seized agricultural land are the highest (Reydon 2007), all reside along the Ring Road. Six of these provinces have had between 80 and 90 percent of the area subjected to land grabbing: Helmand, 90\%; Nangarhar, 80\%; and Nimroz, $80 \%$. And three have had over 100 percent of the land grabbed: Baghlan, 110\%;

Kandahar 111\%; and Logar 190\% (Reydon 2007), indicating that land is being grabbed, and then grabbed again, revealing the high likelihood of conflict between powerful interests over land. In a number of areas of the country land seizures are thought to be organized and run by a 'land mafia' (Irvine 2007; IWPR 2008), with seized land being divided into smaller pieces, and then sold (Irvine 2007).

The pervasiveness of land seizures in Afghanistan creates a number of economic, social, and political instabilities (Sherin 2009; Reydon 2007). The economic development that is thought to follow road reconstruction is actually made more difficult by the illegal seizure of lands, including government owned land upon which development projects are planned (Irvine 2007). The recently enacted National Land Policy states, "land grabbing is one of the most problematic aspects of land management throughout the country" (IRA 2007). The Policy notes that there are a lack of viable enforcement mechanisms, and that Afghans do not have any confidence in statutory courts to resolve land disputes.

Aggravating this is the reality that government officials misuse the law to take control of public and private land (Bowman 2010). And while the Karazi decree 377 makes land grabbing explicitly illegal, as does article 285 of the Legal Code, legal redress is nearly impossible $^{3}$ (InfoSud 2009). There is pervasive distrust of corrupt authorities and courts, particularly involving regaining land ownership, which is a major problem for returning refugees and internally displaced persons (IDPs) (Olesen and Strand 2005)4. Such

\footnotetext{
${ }^{3}$ Complaints to the Human Rights Commission regarding land grabs have doubled over the last two years (Bowman 2010).

${ }^{4}$ Ironside (2010) notes a similar relationship between new roads and land grabbing in Cambodia, where the formal court system involving land rights are also quite corrupt, distrusted, and difficult to gain access to (also Chandet 2010).
} 
corruption and distrust then strongly dissuades people from engaging any services connected with the state land tenure system (laws, titles, inheritance regulations and procedures, the official land market, the recording of transactions, surveying, demarcation, etc.). These are all seen as ways that the officialdom comes to know about the location, size, and potential value of lands and properties, and importantly, who land can be most easily seized from. In this regard increases in access to state services associated with road infrastructure (re)construction, also opens up access to lands for corrupt officials, thus working against peace and economic development. This then encourages a search by local inhabitants for alternatives to state institutions for forms of security of their lands which are able to resist or act against this latter form of access. The Taliban are only too eager to provide such an alternative, especially as this often involves violent actions against state actors and non-Taliban warlords. The Taliban also provide disgruntled and disenfranchised villagers with weapons so they are able to react to depredation by government (Sato 2010). In fact the Taliban are using widespread discontent with the land grabbing problem specifically, as a recruiting tool, as resentment over the problem and desire for retribution and restitution of seized land and property grows (Bowman 2010). This arguably contributes to the growing sympathy and support for the Taliban among the general population (Sato 2010). Complicating this is the reality that elites and warlords will not easily be willing to give up land they have forcibly grabbed from the peasantry (McAuslan 2009). In neighboring Pakistan's Swat Valley, the Taliban were able to gain control by explicitly taking advantage of land issues-landlessness, unresolved land disputes, land related corruption — and the local population's desire for an alternative to a corrupt, ineffective state (Perlez and Zubair 2009).

A complicating factor is the recent discovery of very large valuable mineral deposits in the country (Risen 2010; Rubin and Mashal 2010). The additional road reconstruction needed in order to facilitate mineral exploitation, will very likely result in additional seizures of land which are located both on top of mineral deposits, and along new roads leading to these. Such road construction will also likely encourage the suspicion that the foreigners building such roads are engaged in seizing land containing minerals (Nishimura 2010) — a suspicion likely to be encouraged by the Taliban and by land seizures by powerful actors.

\section{The Context Problem}

While it is appreciated among many in the international community concerned with postwar recovery that the socio-political context in war-torn countries is very different than in stable settings, specifically how it is different, and what this different context means for approaches to certain peacebuilding priorities and their interactions, remains unexamined in a way that is relevant to policies and programming. This section describes the current conflict-related context in Afghanistan for the two peacebuilding priorities discussed here. 


\section{The road (re)construction context}

Decades of war and neglect have reduced Afghanistan's limited roads and bridges to nearly impassable conditions (Glasser 2002). The (re)construction of roads is seen by international donors as a major component of peacebuilding in the country, with a large presumed role in winning over local populations (USAID 2009; USAID 2006; JICA 2004; JICA 2003; JICA 2006; JSCE 2002). Road (re)construction is the second largest absorber of aid money after security expenditures, and the largest component of Afghanistan's economic reconstruction and development (e.g., Delesgues 2007; Olesen and Strand 2005). One source puts the 2001-2009 road rebuilding effort at US 3 billion (Smucker 2009), while other sources note that the majority of the road projects in Afghanistan are being undertaken by the US and Japan, at a cost 'several' billion US dollars (Schell 2009; USAID 2009; USAID 2006; JICA 2004; JICA 2003; JICA 2006; JSCE 2002). Security expenditures by contrast are estimated at 65 billion in 2010 for the US alone (DSN 2009). However as Major-General Tucker, Deputy Chief of Staff for Operations of ISAF in Kabul notes, "[s] ecurity in Afghanistan is ultimately defined by our ability to build and defend the ring road" (Smucker 2009). The current measures of success for road (re)construction are highly selective, easily measured and almost entirely logistical: reduced vehicle costs; lower transport costs, travel times and passenger fares; increases in the number of businesses; an increased volume of traffic; and additional freight moving along roadways (USAID 2009), as well as the symbolic value of road (re)construction as evidence of how assistance is progressing (Delesgues 2007).

While the benefits thought to be connected to road infrastructure construction are numerous, some analysts have expressed concern about the actual impact of (re)construction on local community livelihoods, security, and society in Afghanistan. ${ }^{5}$ Of particular note is the involvement of the Taliban in road (re)construction in the form of demanding money from both the villages to be serviced by roads and construction firms, in exchange for not destroying roads as they are being rebuilt, or kidnapping workers and destroying equipment. As well the Taliban receive money in exchange for guaranteeing the security of truck transportation on roads (Imbert 2010). In this regard, the more reconstruction activity there is, the richer the Taliban and warlords become (Imbert 2010). A recent report by the U.S. House of Representatives notes that one tribal chief

\footnotetext{
5 Delesgues (2007) comments on the enormity of the cost, the increases in insecurity that result, and on the benefits accrued to warlords and other well-positioned elites at the expense of local populations. MacDonald (2005) examines the wide variety of highly problematic issues connected to post-conflict infrastructure (re)development in a variety of countries including Afghanistan: corruption, problems with disenfranchised and marginalized groups, access to essential services, coordination, security, and the aggravation or re-emergence of grievances and tensions. MacDonald (2005) finds further that "in most situations the triggers for conflict can be related to power and/or resources and, while the reconstruction phase provides opportunities to mitigate underlying tension, it is also possible to exacerbate them inadvertently". At the same time Reydon (2007) notes that a primary reason for land grabbing in conflict scenarios is power.
} 
and his associates can make tens of thousands of dollars per year just escorting truck convoys along roadways (USHR 2010).

In a review of the Japanese and American road (re)construction programs, absent was an understanding about any potential detrimental land rights or socio-political outcomes to peacebuilding. For example, for the American infrastructure reconstruction effort a list of 23 Afghan laws thought to be relevant to road reconstruction were taken into account (USAID 2009). Absent from this set of laws were the National Land Law; the Law on Land Management; The Environment Law; the Regulation on the Distribution of Land; Law of Land Survey, Verification and Registration; Law on Land Expropriation; Law on Acquisition and Sale of Land; Restitution; and the Law on Land Dispute Resolution among others; as well as a consideration of any form of customary land law or customary land tenure, which is how most people in the country access and claim land.

A more important concern in post-conflict road (re)construction however is the apparent disconnect between those in the international community who plan, fund, and implement road projects and who see straightforward benefits to economy and society being the direct result; versus local inhabitants on the ground who view such developments in the context of how local to national society currently functions, and which on-going sociopolitical patterns will be enhanced or diminished. The former views benefits of road (re)construction based on generalized conventional understandings of how a market economy, access to services, rule of law, mobility, and security operate in largely stable settings. The latter can view the same (re)construction in the context of who will control the roads and determine who can use them and for what purposes, increases in oppressive processes such as land grabbing, control over agricultural production, speculation, rent seeking, recruitment of indentured labor, and increased access to local villages and other rural areas by outsiders representing a variety of exploitive forces. Such forces include a corrupt government, the Taliban, and the foreign troops who engage them. In fact from the foreign military viewpoint road (re)construction has this latter purpose as an explicit priority (Rogers 2010; Ibert 2010; USAID 2009). Access to local populations is important to the Taliban because this is where most of their money is raised through a very wide variety of rackets, kidnappings, and the smuggling of commodities extracted at the local level such as cedar wood and chromite ore (Ibert 2010).

Presently roads are heavily targeted by the Taliban insurgents (Catarious 2010). In the past year violence in the more peaceful north of the country "has escalated as the Taliban converge on roads that bring supplies from Central Asia to military bases in Afghanistan" (Rahim 2010). The Taliban's use of roads has also allowed their forces to move faster and strike quicker (Nasuti 2009). (Re)constructed roads are also attractive locations for the placement of numerous improvised explosive devices (IEDs) (Shah and Nordland 2010); with the rise in incidents involving IEDs comprising a 94 percent increase in the first six months of 2010, compared to the same period in 2009 (UNSC 2010). With roads a magnet for the placement of IEDs, farmers are having great difficulty accessing their 
lands (Hutchinson 2010). Meanwhile foreign military forces often create new 'military roads', frequently through farms and household compounds, because existing roads are so heavily mined (Shah and Nordland 2010). Roads used for military operations and for extending the reach of government (priorities of the international community) (Rogers 2010) then lead to large increases in security incidents (UNSC 2010) and the associated civilian dislocations from lands and properties, thus severely aggravating the land tenure situation. As a local resident of Dara-e-Pachaye in Kabul's Paghman District noted, "foreign forces came to our village and said they want to asphalt the road but we said no. We know the road is good but we also know that an asphalted road brings ISAF patrols and with them comes suicide and roadside attacks" (IRIN 2010b). In Nuristan province road building is resisted because it is the defense strategy of many communities to remain isolated (Nasuti 2009). At times international forces are called upon by farming villages to destroy bridges used by insurgents (Hauslohner (2010). As well the wide variety of national and international private security forces are known to treat the general citizenry in abusive ways, particularly on the country's roads (Ahmad 2010). The problem is so severe that president Karzai decreed in August of 2010 that all private security groups in the country were to disband, citing the need "to better provide security for the lives and property of citizens' (Ahmad 2010).

Also problematic is the donor assumption that road infrastructure will benefit all or most of society equally, thus the presumed connection to general population-wide economic development and access to services. But conflict related scenarios are very different than stable settings in this regard. Societies in or emerging from conflict are highly fractured, internally divisive, lack rule of law, are usually desperate and grievance-based, have a significant culture of impunity, and experience constant power struggles and their associated forms of subjugation and exploitation. The reality is that roadway (re)development will reside within this conflict context, where seeking advantage or protecting oneself (or one's group) by any means in the absence of effective rule of law, or attempting to prevail over or resist other groups and/or sectors of society is the norm. This is very different than a stable society setting where effective rule of law facilitates a more equitable realization of benefits from road construction, along with protections from the potentially negative changes such construction can also bring.

The presumed 'greater access to social services' which is thought to be a direct outcome of road (re)construction is actually quite complicated. The central assumption is that such services would be provided by the state, local government, NGOs, or internationally funded projects or programs. And that provision of and access to and use of such services by the general population would then contribute to increased well being and hence durable peace. In a land tenure context these services would normally include institutions which provide protections and justice with regard to land conflicts, land grabbing, and restitution of lands and properties; as well as services for surveying, titling, land registration, and the mechanisms for using land as forms of collateral. However in a warrelated context such service provision is in many instances non-existent, weak, or highly 
corrupt - especially for land and property related services, with Afghanistan a primary example. This is something that insurgent groups capitalize on with the insertion of their own services. Social service provision has become a primary way for insurgent groups to gain strength (Berman 2010; Stern 2010). This is why insurgents destroy development and reconstruction projects and target aid workers and state institutions, and promote their own hospitals, schools, courts, and other service-providing institutions (Oppel 2010; Stern 2010), while at the same time intimidating and scaring local populations with attacks and killings for cooperating with government efforts 6 (Hammond 2010). When a local population's only options for justice, security, employment, education and welfare are connected to an insurgent group, the latter is then much more able to recruit and assert other forms of control, including economic gain (Stern 2010). Thus the greater the insurgent monopoly over the normal functions of government, the greater control they have over their constituencies (Bermnam 2010). As a result insurgent groups go to great lengths to establish and maintain their "social service-providing organizational base" (Berman 2010). To the extent that road (re)construction increases access to services, and these are provided and/or imposed by insurgents (and the Taliban are notable in this regard), then road (re)construction would act to detract from durable peace. Hayashi (2010) notes that road (re)construction allows the Taliban to move around easier. And General McChrystal, former commander of all foreign forces in Afghanistan, noted that "in places they [the Taliban] control roads, collect revenues, and mete out swift justice" (IRIN 2010a). Even in government controlled cities, some inhabitants take advantage of improvements in access to travel to Taliban courts for justice, preferring these to the corrupt government alternative (Economist 2010).

\section{The land rights context}

Long periods of contemporary armed conflict beginning with the Soviet occupation have profoundly altered the statutory and customary land tenure systems of Afghanistan. Today land tenure in the country is a confusing and highly divisive array of statutory, customary, ad hoc, Islamic and warlord tenure, rife with problems and lacking in nationally legitimate, workable approaches (Wiley 2003; IWRP 2008). With the capture of the state by the Mujahidin in 1992 there began a period which continues today, of accelerated disarray in land tenure. Tenure security has plummeted, and extortion, asset stripping, and land grabbing thrives as a wide variety of warlords, militias and other groups and powerful interests have emerged over time and seek to acquire lands (Wiley 2003). Customary agreements and land documents have become meaningless, and the poor are unable to pay the necessary bribes to keep the militias away from their lands. As a result land issues are among the most problematic confronting the Afghanistan government (IWPR 2008).

\footnotetext{
6 The UN reports that civilian casualties in Afghanistan were up by 31 percent and assassinations and executions up by over 90 percent in the first half of 2010 (Hammond 2010).
} 
While the success of the current disarmament, demobilization and reintegration (DDR) effort in Afghanistan depends on agricultural lands (Sato 2010), and the long-term stability of the country hinges on recovery and resilience at the local level (Rogers 2010), rural and peri-urban lands are often invaded and degraded, and waves of land seizures have taken place as various individuals and groups have gained and lost power over time (Wiley 2003), and land values have increased dramatically (e.g., Sherin 2009; Irvine 2007; Synovitz, 2003; IRA 2007a; IWPR 2008; Batson 2008; Maletta 2007; InfoSud 2009). For Afghanistan in its current state, three issues in particular combine to create an exceedingly difficult land rights context within which to pursue road infrastructure (re)construction. These are, population dislocation and return, widespread corruption, and landmines and their clearance.

The enormity of the dislocation and return problem in Afghanistan is difficult to adequately describe. While over five million refugees have returned to the country since 2002 (and attempted to re-access their lands and properties) in the world's largest repatriation (USDS 2010), as of 2009 there were still approximately 2.7 million refugees in Pakistan and Iran (UNHCR 2009; Rehmani 2009), and approximately 235,000 individuals internally dislocated (IRIN 2009). At the same time new dislocations continue to occur due to ongoing insecurity and conflict between the Taliban and local populations (Hammond 2010), and between the Taliban and national and international forces. Such massive population displacement results in large-scale abandonment of lands and properties by the original inhabitants; with the intent of the dislocatees being that such abandonment is temporary and that at some point they will return to re-access their lands.

At the same time the pervasive corruption in Afghanistan is widely thought to be a significant factor hindering the country's recovery, and is a primary point of contention between the government and the international community (e.g. UNODC 2010; Gebauer and Volkery 2010). War-torn countries are generally the most corrupt, and Afghanistan ranks the lowest in the world in this regard, alongside Iraq and Somalia (BBC 2009). One study notes that corruption in the country has doubled since 2007 (IWA 2010). A recent $\mathrm{UN}$ report notes that 59 percent of Afghan citizens indicate that corruption is the largest problem the country faces, even larger than security (UNODC 2010). Afghans note that it is impossible to obtain a public service (including presumably, land and property services) without paying a bribe (UNODC 2010). And with corruption higher in rural areas (UNODC 2010), this places legitimate, effective forms of rural land tenure in considerable jeopardy.

A recent study of corrupt practices in the country placed dealing with corruption in the land sector as one of its eight priority recommendations for the country (IWA 2010). Land seizures and the associated evictions are a growing form of corruption, and the corruption money leaving Afghanistan is increasingly coming from land grabs (Bowman 2010). As well, the threat of land seizure is often used as a means of extortion (World Bank et al 2007). Especially relevant to land conflicts is that sectorally, corruption is 
worst in the justice system, with the courts being particularly problematic (IWA 2010), thereby dissuading local populations from using statutory courts to resolve land disputes. With corruption a direct cause of land conflicts at the local level, people are driven into the domain of the Taliban to seek recourse (Carlstrom 2010; Giampaoli and Aggarwal 2010). One study notes that the "[p] pular perception is that property rights are for sale by the government to insiders with influence" (IWA 2010).

The presence of landmines, IEDs and mine clearing activities in Afghanistan constitute a significant impact on the country's land rights problems (Rashid et al 2010). Afghanistan is the most mined country in the world (Okumura 2010), and the mine clearance effort is quite large, with the country having the world's largest and longest established mine action program (UNMAS 2006; LCMM 2010). Some estimates put the number of landmines in the ground as high as 10 million (George 2002). And the communities along the ring road have been highlighted as particularly at risk with regard to the impact of landmines (Villano 2009). At the same time agricultural and grazing land accounted for 95 percent of mined areas (ICBLM 2010) including the most important agricultural and pastoral areas, along with water points and roads and access ways to these (Rashid et al 2010). Once cleared of mines, lands will become available for use and reoccupation, theoretically by the owner or previous inhabitant. However when cleared lands are in proximity to rehabilitated existing or new roads they greatly increase in value, and the political and economic incentive to access them will also be greater. In Afghanistan both mine related dislocation and post clearance land (re)occupation can be extremely difficult in terms of their acutely negative effects on land rights and land disputes (Rashid et al 2010). Rising land values increase the likelihood that cleared land will be grabbed by the powerful or rich, and the magnitude and severity of subsequent land disputes can hinder further clearance efforts and other forms of development (Rashid et al 2010). There are cases in the country where the local community did not want their lands demined, for fear that it will be grabbed by outside powerful interests (Rashid et al 2010). Thus the connections between rural land rights, mine-related problems, and land grabbing in proximity to the ring road where land mine vulnerability is particularly high, would seem to be significant. Similar relationships between land rights and landmines, including the role of roadways, have been reported in Cambodia (AusCare 2008), Mozambique (Unruh et al 2003), Bosnia (Vracic and Vukovic 2010), South Sudan (McMichael and Missleberg 2010), Sri Lanka (Fonseka 2010), and Yemen (Thompson 2010).

\section{Conclusions}

The current logic behind the (re)construction of road infrastructure serving as a "bridge to peace" in Afghanistan (USAID 2009), views (re)construction as a causal driver of an array of benefits which are thought to directly contribute to economic development, peace, and security for the general population. However under conditions such as those experienced in Afghanistan, road infrastructure (re)development acts instead to set in motion a destabilizing set of land tenure processes for a significant percentage of the general population, while benefitting the well placed, wealthy, and powerful, as well as 
the insurgency. While the provincial reconstruction teams (PRTs) put in place by the coalition forces are innovative in terms of their mandate for a combination of security and development, with only about 30 PRTs in the country and their capacity varied and low compared to the need, the task is well beyond what is being provided (Catarious 2010). This is particularly the case because (at the time of writing) important forms of security are deteriorating significantly in a number of regions of the country (Hammond 2010).

Outcomes to the interaction between road (re)construction and land tenure will be highly variable, especially at the local scale. Such that while it will be possible to spot certain local positive effects, an important question is, what is the aggregate outcome of the interaction. In stable settings there are a set of ingredients in place that facilitate an aggregate positive or neutral interaction between these two fundamental components of society (e.g. rule of law, security, viable and legitimate institutions, state legitimacy, etc.), as well as a set of ingredients that are not (insurgent war; sectarian, ethnic and civil strife; war involving foreign forces; warlord law, etc.). Such that it can be argued that the reason for negative aggregate outcomes is the presence or not of these two sets of ingredients, and not road (re)construction per se. However, given the existence of such a conflict context, and the difficulties in changing it into a stable context in anything less than the long-term, an important question is, should road infrastructure (re)construction be undertaken in its present form while such a context is in place. And if not, how should the approach to road infrastructure be changed to more effectively fit within the prevailing context, so that the stated benefits do not accrue solely to a set of well placed actors at the expense of a larger population who are unable to legally, institutionally, and physically defend themselves, except by pursuing volatile alternatives.

An improved assessment of the actual impact of road (re)construction on unstable wartime settings would need to include a realistic examination and understanding of how (re)construction interacts with other aspects of peacebuilding under the prevailing conditions. This would include a realistic assessment of both positive results as well as detrimental outcomes, given the actual socio-political, economic and security conditions on the ground; as opposed to a listing of only presumed positive outcomes based on stable scenarios, which is presently the case. But unfortunately the different components of the peace process as currently derived and implemented are viewed as separate, individual activities able to generate benefits independently, regardless of the status and pace of other interacting components, and without taking into account the fundamentally different nature of unstable, war-torn settings. Certainly part of the reason for this separation is disciplinary (e.g., civil engineering, vs. political science, vs. law, etc.), as well as the manner in which projects for reconstruction are derived, funded, and operationalized. While it may seem self evident that conflict related socio-political contexts are quite different than stable contexts, exactly how different components of peacebuilding interact on the ground is much less well known, and Afghanistan is a vivid example. 


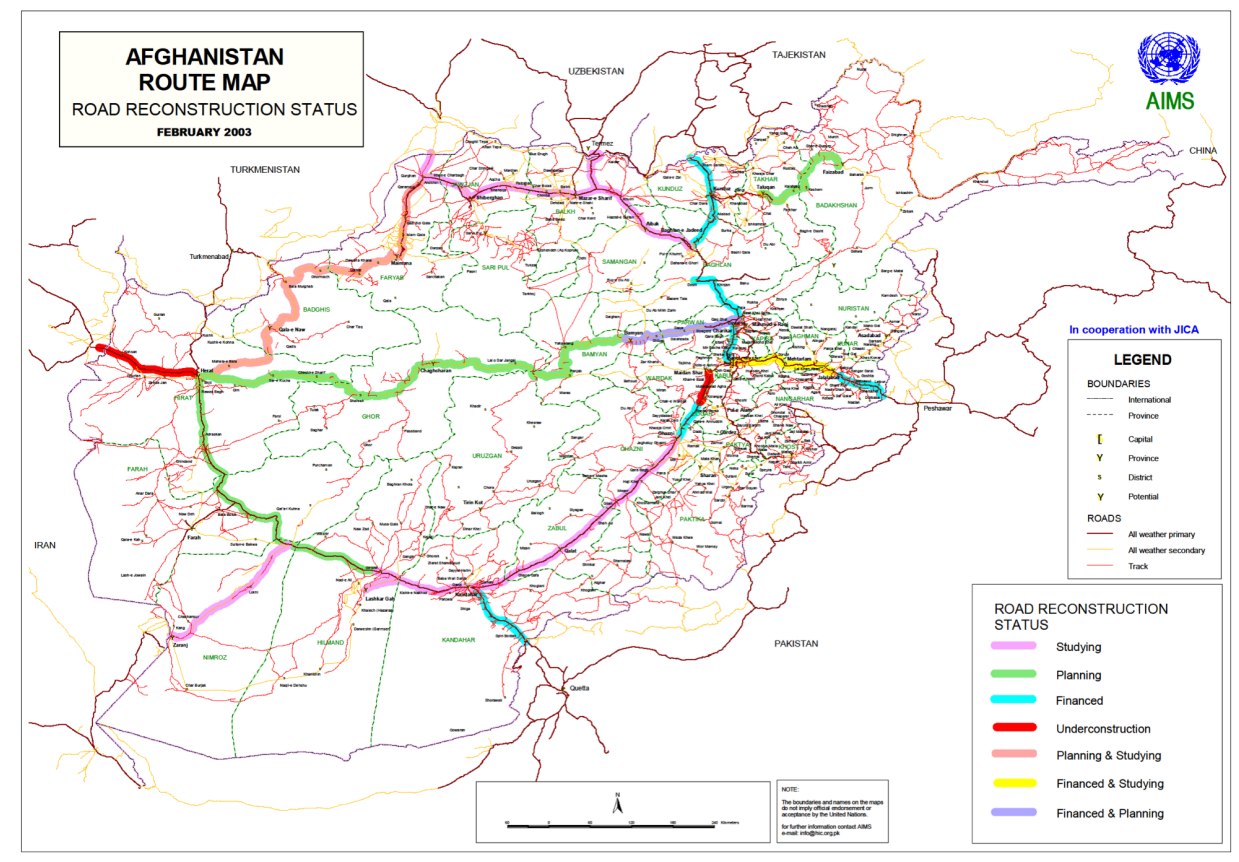

Figure 1. Road (re)construction in Afghanistan 


\section{Bibliography}

Ahmad, S. 2010: Karzai order security firms to disband. National Post and Agence France-Press, August 18.

Andre, C. 2003: Custom, contracts and cadastres in north-west Rwanda. in T.A Benjaminsen and C. Lund (eds.), Securing Land Rights in Africa. London: CASS Publishing.

AusCare. 2008: Tackling poverty in conflict-affected countries: linking development, security and the remnants of conflict. Summary Report of Workshop, 306 November, Hue, Vietnam.

Bailliet, C. 2003: Property restitution in Guatemala: a transnational dilemma. In Leckie S (ed.) Returning Home: Housing and Property Restitution Rights of Refugees and Displaced Persons. Transnational Publishers, Ardsley NY.

Banks, P. 2007: Issues paper on reforming Liberia's legal and judicial system towards enhancing the rule of law.' Governance Reform Commission, Monrovia: Republic of Liberia.

Barquero, R. 2004: Access to land in post-conflict situations: a case study in Nicaragua. FAO, Rome.

Batson, D. 2008: Registering the human terrain: a valuation of cadastre. Center for Strategic Intelligence Research, NDIC Press, Washington DC

BBC. 2009: War-torn nations 'most corrupt' BBC News, Nov 17. http://news.bbc.co.uk/ go/pr/fr/-/2/hi/business/8363599.stm

Berman, E. 2010: Radical, religious and violent: the new economics of terrorism. MIT Press, Boston.

Bowman, T. 2010: Karzai's brother tied to corrupt Afghan land deals. National Public Radio, Feb 1.

http:/www.rawa.org/temp/runews/2010/02/01/karzai-brother-tied-to-corrupt-afghanland-deals.html. visited on 23 April 2010 
Bruch, C., Jensen, D., Nakayama, M., Unruh, J., Gruby, R., and Wolfarth, R. 2009: Postconflict peacebuilding and natural resources. Yearbook of International Environmental Law. 19:58-96

Carlstrom, G. 2010: Study says Afghan graft worsening. Aljazeera, 13 July.

Catarious, D. 2010: The impacts of Afghan and US counter narcotics efforts on the Afghan poppy farmers. Paper presented at the Second International Symposium on Strengthening Post Conflict Security and Diplomacy: Policy Recommendations to Integrate Natural Resources, Infrastructure and Peacebuilding, University of Tokyo, 34-25 June.

Chandet, H. 2010: Whose Land is this Anyway? The Role of Collective Action in Maintaining Community Rights to the Land in Kratie, Cambodia. Paper presented at the International Research Workshop on Collective Action, Property Rights, and Conflict in Natural Resources Management, June 28 - July 1, Siem Reap, Cambodia

Cohen, S. 1993: The Politics of Planting: Israeli-Palestinian Competition for Control of Land in the Jerusalem Periphery. Geography Research Paper No. 236, University of Chicago Press, Chicago.

Delesgues, L. 2007: Afghan roads reconstruction: deconstruction of a lucrative assistance. Integrity Watch Afghanistan, Tiri, London

Development Workshop (DW) 2005: Terra, urban land reform in postwar Angola: research, advocacy and policy development. Development Workshop Angola Occasional paper No. 5, Luanda.

Defense and Security News (DSN) (2009) Afghan war costs to overtake Iraq in 2010:

Pentagon. http://www.defencetalk.com/afghan-war-costs-to-overtake-iraq-in-2010pentagon-18679/ Visited on 1 Dec 2010

Economist (2010) Lunch with the Taliban. The Economist Vol, 397, Num 8706

Fonseka B (2010) Landmines and Land Rights in Sri Lanka. Geneva International Centre for Humanitarian Demining (GICHD), Geneva

Gebauer, M., and Volkery. 2010: Corruption in Afghanistan. Spiegel Online International. 19 January

George, M. 2002: Afghanistan's landmine legacy. BBC, 28 July 
Giampaoli, G., and Aggarwal, S. 2010: Land tenure and property rights in Afghanistan: Do LTPR conflicts and grievances foster support for the Taliban. Property Rights and Resource Governance Briefing Paper 5. USAID, Washington DC.

Glasser, S. 2002: Project to build Afghanistan's roads going nowhere, despite promises. The Washington Post, 7 August

Goovaerts, P., Gasser, M., Inbal, A. 2007:. Demand driven approaches to livelihood support in post-war contexts. Paper No. 29, ILO and World Bank.

Hammond, A. 2010: Civilian casualties up 31\%: UN. National Post, Canada, August 11

Hausloher A (2010) With attacks on US base, Taliban up the ante in Afghanistan. Afghanistan News Center. http://www.Afghanistannewscenter.com/news/2010.

Hayashi, T. 2010: Personal communication. Japan International Cooperation Agency (JICA), Consultative Meeting on Strengthening Post-Conflict Security and Diplomacy: Policy Recommendations to Integrate Natural Resources, Infrastructure, and Peacebuilding, June 25, Tokyo.

Hutchinson, B. 2010: As offensive intensifies, villagers take flight. The National Post, August 27.

Imbert L (2010) The Taliban`s secret weapon: security. Le Monde Diplomatique, 6 Oct, Paris

InfoSud. 2009: Land and home grab in Afghanistan. InfoSud Human Rights Tribune. Geneva.

IRIN. 2010a: Afghanistan: driven into the arms of the Taliban. IRIN Humanitarian News and Analysis, UN Office for the Coordination of Humanitarian Affairs.

IRIN. 2010b: Afghanistan: Military convoys put civilians "at risk". IRIN Humanitarian News and Analysis Service of the UN Office for the Coordination of Humanitarian Affairs.

IRIN. 2009: Afghanistan: Insecurity, lack of aid prompt IDPs to leave camp. IRIN Institute for War and Peace Reporting (IWPR). 2008: Afghan Environmental Health Problems Legacy of Land-Grab Institute for War and Peace Reporting, London

International Campaign to ban Land mines (ICBLM). 2010: Afghanistan: Landmine Fact Sheet . http://www.afghan-network.net/Landmines/ Site visited on 23 August 2010 
IRA (Islamic Republic of Afghanistan). 2007a: Draft Land Policy. Islamic Republic of Afghanistan, Kabul.

Ironside, J. 2010: Personal communication, University of Otago, New Zealand, International Research Workshop on Collective Action, Property Rights, and Conflict in Natural Resources Management, June 28 - July 1, Siem Reap, Cambodia

Irvine, S. 2007: Powerful grab Afghanistan land. BBC News. http://news.bbc.co.uk/go/pr/ fr/-/2/hi/south_asia/6981035.stm

IWA (Integrity Watch Afghanistan). 2010: Afghan perceptions and experiences of corruption: a national survey. Integrity Watch Afghanistan, Kabul.

JICA. 2003: The urgent rehabilitation support program in Afghanistan: Rehabilitation planning of the South Western Area and public transportation study of Kabul. Japan International Cooperation Agency (JICA), Tokyo

JICA. 2006: The project formulation study on Road maintenance and management sector In Afghanistan, Japan International Cooperation Agency (JICA) and Katahira \& Engineers International, Tokyo

JICA. 2004: Afghanistan Assistance: From Reconstruction to Development. Japan International Cooperation Agency (JICA), Tokyo

JICA. 2004: Afghanistan Assistance: from Reconstruction to Development, Japan International Cooperation Agency, Tokyo.

JSCE (Japan Society of Civil Engineers). 2002: Afghanistan Reconstruction Vision, JSCE and Kabul University, Tokyo and Kabul

Junne, G. and Verkoren, W. 2005:. Postconflict development: meeting new challenges. London: Lynne Rienner Publishers.

LCMM (Landmine and Cluster Munition Monitor) .2010: Afghanistan. Mines Action Canada, Ottawa. http://www.the-monitor.org/index.php/publications/display?url=1m/ 2007/afghanistan.html\#ffootnote-1081-60-backlink visited on 10 June 2010

MacDonald, M. 2005: Provision of infrastructure in post conflict situations. Department for International Development, London

Maletta, H.E. 2007: Arable Land Tenure in Afghanistan in the Post-Taliban Era. African and Asian Studies, Vol. 6 
McAuslan, P. 2009: Emergency Lex - and other improbable tales from the law zone.

McMichael G, and Massleberg A (2010) Landmines, Livelihoods and Post-conflict Land Rights, A Case Study of Southern Sudan. Geneva International Centre for Humanitarian Demining (GICHD), Geneva

Meilahn, K. 2007: Cultural Understanding within Context as a Tool for Countering Irregular Threats and as a Force for Peace, Strategic Insights, Volume VI, Issue 2

Ministry of Rural Rehabilitation and Development and Ministry of Public Works (MRRD/MPW). 2007: National Rural Access Program (NRAP), Ministry of Rural Rehabilitation and Development and Ministry of Public Works, Kabul.

Mockaitis, T. 2003: Winning hearts and minds in the 'war on terrorism', Small Wars \& Insurgencies 14: 21-38(18)

Nasuti M (2009) The Ring Road: A Gift Afghanistan Cannot Afford. The Kabul Press, Kabul.

Nishimura, M. 2010: Personal communication, Japan Institute of International Affairs (JIIA), Consultative Meeting on Strengthening Post-Conflict Security and Diplomacy: Policy Recommendations to Integrate Natural Resources, Infrastructure, and Peacebuilding, June 25, Tokyo.

Okumura, R. 2010: Personal communication. Osaka School of International Public Policy, Osaka University, Japan.

Olesen, G., and Strand, A. 2005: Evaluating post war interventions: the case of Afghanistan. Danida, Copenhagen.

Oppel, R. 2010: Bombers hit US aid compound in Afghanistan. The New York Times, July 3

PakTribune. 2003: UN accuses top Afghan ministers of land grab. PakTribune, September 12, http://www.rawa.org/land.htm

Perlez, J., and Zubair, P. 2009: Taliban Exploit Class Rifts in Pakistan. New York Times, April 16

Rahim, G. 2010: Taliban kill 5 during raid on US aid group. Agence France-Presse, July 3.

Rashid MS, Jan M, Wakil M (2010) Landmines, livelihood, and post-conflict land rights, the case of Afghanistan. Mine Action Coordination Centre of Afghanistan, Kabul. 
Rehmani, F. 2009: 100,000 refugees return home. Pajhwok Afghan News. Sept 29.

Kabul.

Reydon, B.P. 2007: Social embeddedness, institutions for rural land management and land grabbing, the cases of Brazil and Afghanistan. Unpublished manuscript.

Risen, J. 2010: US identifies vast mineral riches in Afghanistan. New York Times, June 13

Rogers, W. 2010: Military to military engagement on environment and natural disasters: lessons learned for post conflict peacebuilding. Paper presented at the Second International Symposium on Strengthening Post Conflict Security and Diplomacy: Policy Recommendations to Integrate Natural Resources, Infrastructure and Peacebuilding, University of Tokyo, 34-25 June.

Rubin, A., and Mashal, M. 2010: Afghanistan Moves Quickly to Tap Newfound Mineral Reserves, The New York Time, June 17.

Sato, M. 2010: Demobilization, reintegration and natural resources in Afghanistan: Afghanistan's new beginnings programme (ANBP). Paper presented at the Second International Symposium on Strengthening Post Conflict Security and Diplomacy: Policy Recommendations to Integrate Natural Resources, Infrastructure and Peacebuilding, University of Tokyo, 34-25 June.

Schell, B. 2009: Afghanistan: A White Elephant Called The Ring Road. IDNInDepthNews Service. http://www.indepthnews.net/news/news.php? key $1=2009-10-05 \% 2003: 29: 19 \&$ key $2=1$ accessed 6 Nov 09 .

Shah T and Nordland R (2010) NATO is razing booby-trapped Afghan homes. The New York Times, Nov 16.

Sherin, L.A. 2009: Land and home grab in Afghanistan. Human Rights Tribune www.infosud.org

Smucker P (2009) Afghanistan's road to somewhere. Asia Times, Hong Kong

Stern, L. 2010: Do-gooder terrorism. Canwest News Services, 1 June 
Synovitz, R. 2003: Afghanistan: Land-Grab Scandal In Kabul Rocks The Government. Radio Free Europe/Radio Liberty, Washington DC.

Thompson H (2010) Landmines and Land Rights in Yemen. Geneva International Centre for Humanitarian Demining (GICHD), Geneva

UNEP (United Nations Environment Programme). 2009: From Conflict to Peacebuilding: The Role of Natural Resources and the Environment. United Nations Environment Programme, Geneva

UNHCR. 2009: UNHCR and Pakistan sign new agreement on stay of Afghan refugees. UNHCR

UNMAS. 2006: UN, “Country Profile: Afghanistan,” www.mineaction.org; email from unnamed program officer, UNMAS, 20 July 2006; interview with External Relations Officer, UNMACA, 15 April 2007.

UNODC. (UN Office on Drugs and Crime) 2010: Corruption in Afghanistan: bribery as reported by the victims. UN Office on Drugs and Crime

Unruh, J.D. 2009: Land rights in postwar Liberia: the volatile part of the peace process. Land Use Policy 26: 425-433.

Unruh, J.D., Heynen, N.C., Hossler, P. 2003: The political ecology of recovery from armed conflict: the case of landmines in Mozambique. Political Geography 22: 841-861

Unruh, J.D. 2003: Land tenure and legal pluralism in the peace process. Peace and Change: A Journal of Peace Research 28: 352-376.

Unruh, J.D. 2004: Rural property rights in a peace process: lessons from Mozambique. In: Warf B, Janelle D, Hanson K (eds.) WorldMinds: 100 Geographical Perspectives On 100 Problems. Kluwer.

UNSC (UN Security Council). 2010: Report of the Secretary-General pursuant to paragraph 40 of resolution 1917 (2010). United Nations Security Council report S/ 2010/318, New York

USAID .2009: http://afghanistan.usaid.gov/en/Program.25b.aspx Visited 4 Nov

USAID. 2006: Data Sheet: Afghanistan, Agriculture Program, Economic Growth, Agriculture and Trade Pillar. US Agency for International Development (USAID), Washington DC, 
US Department of State (USDS). 2010: Background note: Afghanistan, Bureau of South and Central Asian Affairs, Washington Dc.

US House of Representatives (USHR) (2010) Warlord Inc.- - extortion and corruption along the US supply chain in Afghanistan. US House of Representatives, Washington DC, 22 June

Villano, P. 2009: Afghanistan: landmine clearance safeguards communities one square kilometer at a time. Dipnote, US Department of State, Washington DC.

Vračić A, and Vukovic S (2010) Landmines and Land Rights in Bosnia and Herzegovina. Geneva International Centre for Humanitarian Demining (GICHD), Geneva

Wiley, L. 2003: Land rights in crisis: restoring tenure security in Afghanistan. Afghanistan Research and Evaluation Unit, Kabul.

World Bank, Asian Development Bank, DFID, UNDP, UNDOC. 2007: Fighting corruption in Afghanistan: a roadmap for strategy and action. Discussion Paper by World Bank, Asian Development Bank, DFID, UNDP, UNDOC 